\title{
Analysis of E-textbooks: Development, use and availability on the Slovenian Market
}

\begin{abstract}
Through several projects in Slovenia, e-learning materials have been developed over the last decade, with some primary and secondary schools already using them successfully in their educational processes for several years. The objectives of this research were to analyse the development of e-learning materials, in particular the process of creating e-textbooks, to identify experiences in the use of e-learning materials and to determine their availability on the market. In order to understand the development process, our research involved the creation of $i$-textbooks. The problems we encountered during the creation of $i$-textbooks are presented in this article. The results showed that teachers are satisfied with the use of previously developed e-learning materials. They also agreed that traditional textbooks cannot be replaced completely by e-textbooks. However, they do represent an important motivation tool that assists them in facilitating the transfer of knowledge and helps learners to better understand and learn the contents of different subjects. The e-learning materials present on the Slovenian market are freely accessible or require payment, depending on the editor. A great deal of e-learning materials is also inactive, as was emphasised in our research.
\end{abstract}

Urška Stanković Elesini (1), Grega Tomažin (1)

University of Ljubljana, Faculty of Natural Sciences and Engineering, Department of Textiles, Graphic Arts and Design, Ljubljana, Slovenia

Corresponding author: Urška Stankovič Elesini e-mail: urska.stankovic@ntf.uni-lj.si

First recieved: 25.08.2017. Accepted: 21.11.2017.

\section{KEY WORDS}

e-learning material, learner, project, publisher, teacher

\section{Introduction}

According to the findings presented in the EU Kids Online research (2014), Slovenian children spend an average of 74 minutes a day on the internet (younger children spend less time, while older children spend more). They go online both at home and in school. The most digitally literate are Finnish children, followed immediately by their Slovenian peers. While online, children visit social networks, send messages and watch videos. They also use the internet for their school work and tasks, and for other purposes. The generations of children attending our schools today have literally been surrounded by information and communication technologies (ICT) since birth. ICT are part of their lives and as such they (unknowingly) transfer them to educational institutions, which have been forced to adapt systems, programmes, methods and tools to inevitable progress. The introduction of ICT in the educational process means not only the introduction of new tools, but also changes to the roles of the learner (Table 1) and teacher, the use of new teaching methods (e.g. flipped learning), and thus the new role of the textbook (Kreuh, Kač \& Mohorčič, 2011).

The textbook represents the basic teaching material for the achievement of the educational goals and standards of knowledge defined in a specific curriculum. A textbook may take printed, electronic or printed and electronic form (Official Gazette of the Republic of Slovenia, 2015). Electronic textbooks (e-textbooks) have made great strides at educational institutions over the last decade. The main difference between traditional and e-textbooks lies in the digitalisation of the entire learning environment. In addition to traditional elements (text and graphical presentations), the latter also include interactive elements (didactic applications, games, animations, etc.) and multimedia elements (simulations, videos, sounds, etc.). There is also a difference in terms of accessibility to 
e-textbooks. As a rule, e-textbooks are accessible on the web regardless of time and place, while that accessibility is dependent on the user's internet connection (possible solutions include working on a computer without a connection or on smaller mobile devices, both of which limit the use of e-textbooks). According to Kreuh (2011), an e-textbook represents learning material in a digital learning environment. An e-textbook retains all of the properties of a traditional textbook, while technological progress facilitates access to the other learning resources, promotes active and cooperative learning, offers various ways of solving problems, and provides the learner the opportunity to monitor and evaluate their personal learning progress.

\section{Table 1}

Role of learner in traditional education and e-learning (Bregar, Zagmajster and Radovan, 2010)

\begin{tabular}{|c|c|}
\hline $\begin{array}{l}\text { Learner in traditional } \\
\text { education }\end{array}$ & Learner in e-learning \\
\hline Passive learning & Creator of own knowledge \\
\hline $\begin{array}{l}\text { Learning facts without } \\
\text { deeper understanding }\end{array}$ & Solving of complex problems \\
\hline $\begin{array}{l}\text { Unilateral treatment } \\
\text { of content }\end{array}$ & $\begin{array}{l}\text { Content is considered } \\
\text { from different aspects }\end{array}$ \\
\hline $\begin{array}{l}\text { Individual learning; } \\
\text { solving of own tasks }\end{array}$ & Learning in teams; cooperation \\
\hline $\begin{array}{l}\text { Subordinated to } \\
\text { teacher's assessment }\end{array}$ & $\begin{array}{l}\text { Designing of own questions } \\
\text { and the search for answers }\end{array}$ \\
\hline $\begin{array}{l}\text { Active in only one } \\
\text { cultural context }\end{array}$ & Increased cultural awareness \\
\hline $\begin{array}{l}\text { No influence over rhythm } \\
\text { and tempo of learning }\end{array}$ & $\begin{array}{l}\text { Autonomous, independent } \\
\text { management of time and } \\
\text { the learning process }\end{array}$ \\
\hline $\begin{array}{l}\text { Only feedback about } \\
\text { work is from teacher }\end{array}$ & $\begin{array}{l}\text { Discussion about work } \\
\text { and progress with teacher } \\
\text { and other learners }\end{array}$ \\
\hline $\begin{array}{l}\text { Emphasis on the reproduction } \\
\text { of teacher's knowledge }\end{array}$ & $\begin{array}{l}\text { Emphasis on the creation } \\
\text { of knowledge and the } \\
\text { application thereof }\end{array}$ \\
\hline $\begin{array}{l}\text { Only prescribed learning } \\
\text { materials used }\end{array}$ & $\begin{array}{l}\text { Access to multiple } \\
\text { learning sources }\end{array}$ \\
\hline
\end{tabular}

The objectives of our research were:

1. to analyse the process of creating e-textbooks in practice and to highlight some of the associated problems;

2. to analyse the use of i-textbooks among teachers who have been using i-textbooks for the last several years; and

3. to analyse the Slovenian e-learning materials market, in particular e-textbooks.

\section{Categorisation of E-textbooks}

Technically, an e-textbook is a textbook in a digital format that can be used on computers and saved on different data carriers. An e-textbook is therefore a digital teaching source or an asset stored on electronic media that can be used to replace printed media. Technical tools are, however, required for the use of an e-textbook (Kreuh, 2011). Pesek, Zmazek and Mohorčič (2014) categorise e-textbooks to three levels. The first level comprises so-called digitalised textbooks or d-textbooks, which are electronic copies of printed textbooks in PDF or EPUB2 format. D-textbooks can be read/ displayed by applications that facilitate the addition of bookmarks, records and work with interactive tables. The second level includes so-called rich textbooks or r-textbooks, which are d-textbooks upgraded with sounds and videos. Because some r-textbooks also have simple integrated questions that provide simultaneous feedback to learners, they are quite popular among publishers. Interactive or i-textbooks comprise the third level of e-textbooks. The content of such textbooks is adapted to human-computer interaction. I-textbooks include interactive elements (e.g. video, soundtracks, computer animations, hyperlinks and, in the future, most likely augmented reality, which will be popular in presentations of practical samples) and interactive examinations (instant and significantly improved feedback). They also facilitate the storage of responses, the analysis of effectiveness and the monitoring of users.

\section{Slovenian Projects Involving E-textbooks}

The introduction of electronic learning materials (hereinafter: e-learning materials) in Slovenian primary and secondary schools has proceeded under the auspices of governmental organisations. The Guidelines for the evaluation of e-learning materials, which were linked with the Trubar catalogue for learning materials, were prepared in 1995. The first tenders for smaller projects addressing the preparation of online e-learning materials were released after 1997. E-learning materials were prepared by certain individual teachers or groups of teachers in the scope of the aforementioned projects (Pesek et al. 2014).

In 2006, an action plan for continuing scholastic informatisation (Lesjak, 2006) was presented. The plan stated that the role of learners is changing from passive to active, and that all ICT tools can be used. The role of teachers is changing from that of knowledge "provider" to tutor and education coordinator, as well as moderator for the evaluation of information. The existing services of the school system are changing, while new services are being developed. The system is thus taking on a greater role in terms of the assessment and application of development results, and in terms of connecting the system with the outside world (e.g. the economy). According to the aforementioned plan, it was neces- 
sary to expand the offer of e-learning materials, and to raise the level of those materials to modern, qualitative and (publicly) accessible e-materials that exploit the opportunities presented by the media (e.g. interactivity and multimedia). From 2006 to 2008, the first calls were made for projects addressing the preparation of extensive online e-learning materials. Those materials were drawn up in accordance with relevant curricula. They included interactive and multimedia elements and were freely accessible. (Flogie \& Čuk, 2015)

Slovenia's Development strategy for the information society (Vlada republike Slovenije, 2007) stated that the main subject of the informatisation of the learning and teaching process is the learner, while the teacher is a critical factor for success. The teacher must accept advanced ICT, which will not replace or eliminate traditional learning, but will offer an additional opportunity to change the learning and teaching process, making it more effective and attractive. E-learning is a tool used by learners to obtain additional resources that are not simply passive, but take multimedia and interactive forms. The learning process thus becomes more effective and user-friendly, can be used anywhere at any time, and facilitates examinations, team work (web classrooms), research work and remote learning.

In the period s2009 to 2013, the first extensive project was implemented under the name E-education (Ministrstvo za izobraževanje, znanost in šport, 2016; Stankovič, 2010). Two smaller sub-projects were implemented in the scope of the aforementioned project: E-competent teacher and E-support. After the project was completed, teachers and schools tested and evaluated e-learning materials and e-services via two additional projects: E-textbooks for science classes in primary school, the objectives of which were to upgrade existing e-materials to modern, freely accessible e-textbooks, to evaluate their usefulness in the teaching and learning process and to identify requirements for their proper use (ICT infrastructure, specific training for teachers, etc.) (Pesek, 2013). A new project under the name E-Schoolbag (Slovensko izobraževalno omrežje, 2013) was kicked off after the successful implementation of the E-textbooks for science classes in primary school project. The main objective of the E-Schoolbag project was to develop i-textbooks for the field of social sciences for the eighth and ninth grades of primary school, and for the first year of secondary school (gymnasium). Another objective was to ensure accessibility to and support for newly developed e-services and e-content. The project was based on the three pillars of the 21st century school: the establishment of an e-learning environment, the development of appropriate e-content and the training of e-competent teachers. In order to test e-content and e-services, the participating teachers and learners were equipped with tablets, while all participating schools were equipped with a wireless network. The E-Schoolbag project was com- pleted in November 2015. In January 2016, the results of the above-mentioned projects were published (Pesek, 2013) and are also summarised below in this article.

In 2014, 44 schools were chosen to participate in a pilot project under the name Testing e-learning contents and e-services. Learners were equipped with tablets or computers provided by their schools. During testing, the main emphases were on planning lessons, focusing on the added value of achieving objectives through the use of ICT, and on evaluating learners' achievements.

Projects relating to the e-learning environment in primary and secondary schools have been mostly completed. However, the search continues for efficient and lasting systemic solutions for the editing and maintenance of existing e-materials and e-services, while technical support will also be required as new ideas emerge and are implemented (Sambolić, Beganović \& Čuk, 2016). Consequently, new projects have already been launched this year. As was concluded in a study by Hopson, Simms and Knezek (2001), the positive effects of using technologies in teaching lead to learners' desire to continue using those technologies, ever after a project is completed.

In terms of higher education in Slovenia, the faculty members of universities have implemented several individual and integrated projects that mainly involved the installation of the ICT infrastructure. Some members have participated in various (particularly European) projects in which they secured funding for the establishment of key elements of e-learning. Some members were also involved in the aforementioned projects as advisers and to develop specific activities. There is a huge divide in the use of the ICT among university faculty members. Some members use web classrooms (in general two systems are in use: Moodle and the home-developed Echo system) that are primarily used for publishing/storing e-learning materials, videos and tutorials and for communication with students. Students use web classrooms to download their seminar work or learning materials provided by teachers. We believe that teachers are still using traditional learning methods and approaches, focusing primarily on them instead of the student.

According to the Development strategy for the information society until 2020 (Digital Slovenia, 2016), support should also be given to projects aimed at the modernisation of higher educational didactics, through the requisite use of ICT and the transition to digital education. Innovative and flexible forms of teaching should also be established. Consequently, a call was issued this year for the inclusion of ICT into the higher education pedagogical process for a period of four years. 


\section{Impact of E-textbooks on the Learning Process}

It is evident from research performed in 2009 in Nordic primary and secondary schools that the use of e-textbooks improves the quality of teaching and learning process and the educational performance of learners (OECD, 2009). The use of e-textbooks promotes an inductive way of learning, in particular learning through discovery (Kreuh, 2011), as multimedia and interactive content motivates learning, and improves attention span and the ability to follow instructions (O'Bannon, Skolits and Lubke, 2017). The didactic aspect of an e-textbook emphasises the active role of the learner, encourages the development of basic competences (Kreuh, 2011), facilitates the search for information (Mayer and Moreno, 2002), assists in problem solving (Zheng, Miller, Snelbecker and Cohen, 2006) and the collaborative creation of knowledge, and supports individualisation and differentiation in learning (Kreuh, 2011; Hamed and Ezaleil, 2015; Calcaterra, Antonietti and Underwood, 2005). It also promotes self-regulation (i.e. improved self-organisation) (Zahlut, 2011), different ways of learning and methods for assessing knowledge, etc.

The results of the projects implemented in Slovenian primary and secondary schools indicated that knowledge acquired through the interactive elements of e-textbooks was better. Consequently, the results for most subjects were several percentage points higher. Most teachers assessed the introduction of e-textbooks in the classroom positively. The interactive and multimedia elements in e-textbooks (simulations, animations, multimedia, 3D computer models, experiments, etc.) were assessed as useful for presenting new content to learners, for individual work and for reinforcing acquired knowledge. Teachers noted that the use of e-textbooks stimulated interaction between the teacher and learner, and contributed to learners' motivation and participation during lessons. They did not note significant changes in attention and motivation. By using an e-textbook, they also identified improved collaborative learning. However, the verification and consolidation of content remain at the about same level as when traditional textbooks are used. Teachers were also forced to use different didactic strategies on account of e-textbooks, while their autonomy and workload did not change. They spent more time for preparation, had poorer control over work, technical problems during use and problems associated with a lack of ICT knowledge (Pesek, 2013).

Insufficient knowledge about ICT was also discussed by Hren and Dinevski (2012/2013) in their research. They noted that teachers were not familiar with the capability presented by e-textbooks, and thus did not use them during class. They also emphasised that e-textbooks were an important didactic tool, which through meaningful use helped learners improve the knowledge they acquired. However, learners were more active during lessons in which they used e-textbooks. They used e-textbooks most frequently to search for information and for individual work, while they rarely used them for watching simulations, doing homework, and analysing data and information. Learners were motivated to learn and solve tasks from e-textbooks. They did, however, still prefer traditional (printed) textbooks for learning at home and doing homework. In his research, Krajnc (2011) concluded that ICT increased motivation for learning, but could be also very disruptive if the learner was not sufficiently organised and focused on the learning process. He emphasised that only an experienced teacher with ICT knowledge successfully conducted a lesson in which ICT tools were used meaningfully.

Interesting and similar findings were also obtained in different research conducted by students and teachers in higher education. Research performed by Rockinson-Szapkiw, Courduff, Carter and Bennett (2013) showed that students who used e-textbooks learned actively, while no difference in cognitive learning or final grades were noted. Surprisingly in this research, only $19.7 \%$ of all responding students decided to use e-textbooks for learning, while the rest chose traditional printed textbooks. The preferred use of traditional textbooks over e-textbooks was also described in research conducted by McGowan, Stephens and West (2009). The reason stated for this phenomenon was that students find printed text easier to read and locate, in turn making it easier to learn. Accordingly, bookmarking in traditional textbooks was simpler than in e-textbooks. The same conclusions were also reached in research conducted by Zabukovec and Vilar (2016) among Slovenian students. It was determined in the aforementioned research that printed learning materials increased students' focus while studying, facilitating their active work with learning materials (e.g. marking). They used e-learning materials for searching and superficial reading, or for reading just to become familiar with a particular topic. For more in-depth learning, they made a print version of e-learning materials. However, development is also moving in this direction. In research conducted by Noriyuki and Chunming (2014), the stylus pen was introduced for use with e-textbooks. They concluded that the marking of text with such a pen demonstrated potential in the use of e-textbooks among students. Another important finding in research carried out by Zabukovec and Vilar (2016) was that Slovenian students are not sufficiently trained for searching, evaluating and actively using e-learning materials. Some programmes are in place at faculties for computer literacy, but they are not implemented systematically. Furthermore, active work with e-learning materials increased in conjunction with the increased level of study because of the experiences that students gained during study, and because e-learning materials are included in courses with increasing frequency. 


\section{Creation of E-textbooks}

The creation of an e-textbook is very similar to the creation of a traditional textbook, with the exception of $r$ - and i-textbooks to which interactive elements are added. Authors, reviewers and designers are usually needed when creating a traditional textbook. However, other experts are also needed when creating an e-textbook, including programmers or technicians who make a textbook interactive, and consultants who are responsible for the didactical content of an e-textbook. The most important element among all participants is proper communication, otherwise the process may be interrupted and delayed.

Authors, reviewers, the project manager and technicians must know the capabilities of the software tool that they use for the creation of an e-textbook. Taking into account the valid curriculum, authors first draft the content of an e-textbook. This phase must include the precise definition of the purpose and learning objectives, basic content units and their breakdown into sub-units, together with the appropriate learning activity. The overall design and graphic design of previously drafted content is defined in the next phase, while a decision is made regarding the media that will be used in the textbook. In practice, the two previously described phases are carried out in parallel. However, content must always take precedent over design and technology solutions. After content (scenarios) is reviewed and proofread, technicians enter the content in the relevant program (Pesek, 2014a). The resulting draft version of the e-textbook is then reviewed, commented on, analysed, corrected and finally re-entered in the program. When an e-textbook is finished, it is published online.

Before creating a new e-textbook, it is important to know which authoring tool will be used to create the textbook. A great deal of e-content was created in Slovenia using an eXe authoring tool. Because the further development of that tool has ceased, an updated version (eXeCute) was developed as part of the E-Schoolbag project. The exeCute has now user interface in the Slovene language, the working environment is similar to an LMS (learning management system) learning environment and as a free autonomous tool does not require an internet connection (Kelenc, Kos, Kren and Pesek, 2011). In this way, eXeCute becomes a useful tool for the preparation and production of modern i-textbooks (Kelenc, 2011). In the scope of the E-Schoolbag project, a store with interactive content called EduStore (Ministrstvo za izobraževanje in šport, 2015) was also developed, and connected using a web-based editor, XML interface and clients for individual systems (Windows, Android and iOS). This means that an e-textbook created with another tool can be transferred to the new EduStore (Ministrstvo za izobraževanje in šport, 2015) or a web catalogue. The advantages of the entire system include free access and its open-source.

\section{Methodology}

In order to better understand the process and problems encountered in the creation of an e-textbook, we participated in the creation of i-textbooks for a foreign language for the seventh, eighth and ninth grades of primary school. Development was carried out during the 2014/2015 scholastic year. I-textbooks were created using the eXeCute authoring tool (Kelenc, 2011). We encountered both technical and organisational problems during the creation process, as described below. We were able to solve most problems, but some remain open for discussion, including the following: the optimisation of learning materials for use on mobile phones, as the application in question only works optimally on tablets and computers; the availability of i-textbooks for Mac OSx; the further development of the eXeCute tool; the introduction of analytics to gather data about e-textbooks usage; and the use of the eye-tracing method for analysing the usefulness of e-textbooks. All the above areas were discussed with the technicians responsible for the technical side of e-textbooks in the E-Schoolbag project.

Another of the objectives of our research was to analyse the advantages and disadvantages associated with the use of e-textbooks. As part of this analysis, 12 teachers (representing $20.3 \%$ of those involved in the E-Schoolbag project) were interviewed. Among respondents, 25.0\% use i-textbooks for one year, $50.0 \%$ for two years and $25.0 \%$ for more than two years. After we received and analysed the opinions of teachers, new questions arose about the real use of e-textbooks, evidence and a vision for the future. Answers were obtained through interviews with people responsible for Slovenian e-content projects.

Our research also focused on the Slovenian e-learning materials market, in particular e-textbooks. For that purpose, we searched the internet sources/pages of different publishers, ministries, organisations, etc., and contacted some in search of reliable answers. During our research, we analysed 10 different publishers, e-textbooks issued by the National Education Institute Slovenia and different e-platforms containing e-learning materials.

\section{Results and discussion}

\section{Experience Gained in the Development of an I-textbook}

An i-textbook was created using the eXeCute authoring tool. Initially, a "tree-structured" scenario was studied and the structure of the i-textbook set up. Individual pages took the form of html documents that were linked together automatically into an i-textbook by the eXeCute tool itself. Those html documents/pages were then populated with objects. The eXeCute tool offered 20 objects such as text, tasks, images, videos, links, etc. 
However, an individual object can also be developed and inserted (Kelenc, 2011). When the draft version of the i-textbook was finished, it was reviewed and corrected taking into account the comments of authors, and then published online. Organisational and technical problems were identified while creating i-textbooks. Some of those problems were quickly resolved, while others were more complex and are discussed below.

The eXeCute authoring tool was first downloaded to a computer. However, that computer was an Apple MacBook Pro and we encountered some initial problems. The eXeCute tool was only supported by Microsoft Windows, so we were forced to download programs that support Microsoft Windows applications. The best solution was the CrossOver application (CodeWeavers Inc., St. Paul, Minnesota), which can be used to run Microsoft applications. The CrossOver application also facilitated more accurate work, as the probability of mistakes while copying text from scenarios to the program was quite low. The creation of an i-textbook began after the aforementioned problem was solved.

Creating an e-textbook is a project; not a routine project, but a "research route" on which different problems must be solved. Nevertheless, the planning of activities is always extremely important, otherwise those activities are not executed in the appropriate order and in a timely manner, resulting in project delays. During our project, instructions for different activities were frequently given during the course of ordinary work as problems/changes arose. Thus, instead of working on planned activities, other activities were added unexpectedly, resulting in the delay of the project. Examples of activities that affected the time required and increased the scope of work involved in the creation of the i-textbook are as follows:

1. Sometimes content was inserted into a page before a scenario was complete, and was thus inserted as many as three times after the authors and reviewers finished a scenario.

2. The authors sometimes planned too much text for a page, resulting in the addition of a text button. Because the authors and reviewers did not reach consensus about this solution, text was transferred several times using the button, to the screen image and back.

3. The eXeCute tool facilitated the insertion of five main types of tasks: right-wrong questions, the completion of tasks, the selection of tasks, the linking of tasks and applets (Java Applet for small programs), which required the input of programmed tasks. The design of all tasks (except applets) was pre-programmed and unfortunately often unsuitable, while disagreements arose between the authors and reviewers. On the other hand, one advantage of the applets was the possibility of graphically designing tasks. For this reason, applets were used most frequently. However, the making of applets required much more time than was planned.

4. Our aim was to establish records of images with precise traceability. In our case, however, the traceability of images was very poor, and again more time was spent to find a specific image than was expected. A simple job thus became time consuming and required a great deal of concentration and patience.

5. When a required image (photograph) was not found on the internet or obtained by the author, a photograph was taken or a picture was drawn, and in some case a scenario was actually changed (by the author). All such changes took a great deal of time and required additional work.

Several technical problems with the eXeCute programme were also identified:

1. Photos were only loaded into the program separately and not at the same time;

2. The pop-up windows were hidden behind the main window, so the uploading of images requires a great deal of unnecessary work;

3. Because of inadequate sorting, some problems with the loading of MP3 files were identified;

4. Problems were also identified with the loading of video formats that were not displayed on a specific browser because of an incorrect encoding record;

5. The program arbitrarily added spaces and other characters in the html code, making it difficult to find phrases in the code that did not work properly;

6. Some problems were identified when inserting applets. For example, when a basic code such as JavaScript, CSS or html was added, paddings and margins were incorrect; and

7. Content was expected to adapt to the size of the screen (responsive design) during export, but this was not the case. The i-textbooks were written using the HTML5 standard, but the exported learning material was still not adapted to the size of the screen. The content was only optimised to a certain size or resolution.

Given the aforementioned shortcomings of the eXeCute tool, the following corrections were planned in 2014 (Flogie, Milekšič, Čuk \& Jelen, 2014): (1) a new editor that will include all functionalities with the necessary upgrades so that no local installation of the program will be required; (2) the storage of data will be facilitated using the Arnes cloud (Academic and Research Network of Slovenia), where the eXeCute program will be running; and 3) other functionality for the creation and design of advanced e-content will be added.

By the end of the E-Schoolbag project in 2015, all learning materials were transferred to a newly developed web editor named eUrejevalnik (Zavod Republike Slovenije za šolstvo, 2015b), from which e-learning materials 
could be exported into formats appropriate for use on tablets and mobile phones. The basic idea was to also upgrade and transfer e-learning content to the web environment, so the creation of an e-textbook would be possible using any operating system. eUrejevalnik is an open source solution and its source code is available free under the terms of the AGPL 3.0 license at Sourceforge. net (Slashdot Media, 2017) for all potential developers. The use of eUrejevalnik is rather intuitive, while user instructions and guidance are lacking. E-learning materials should also be analysed with data analytics for future developments and updates. In terms of i-textbooks, it would thus be worthwhile to implement analytics that would provide more precise information regarding which i-textbooks are being used more frequently, which content is viewed more, the number of clicks on individual chapters, tasks, etc. The same web analytics have been used for years for website visits to facilitate the further optimisation of web pages.

In addition to the technical problems that were more or less successfully resolved, an important administrative problem emerged. The rights for the use of content with a recognised copyright (historical photographs, paintings, sound recordings, etc.) cannot be purchased for use in i-textbooks because they are licensed under a Creative Commons licence. Due to these problems, the competent ministry will have to adopt a strategy for the development, publication and maintenance of i-textbooks that would ensure the further development of i-textbooks in Slovenian schools (Pesek, 2013).

\section{Advantages/Disadvantages of E-textbook Use}

During our research, we obtained the opinions of teachers regarding the advantages and disadvantages of e-textbooks. A total of $83 \%$ of teachers said that electronic, primarily i-textbooks are excellent, but not comparable with traditional textbooks, while only $17 \%$ of teachers thought that i-textbooks are inferior to traditional textbooks.

One advantage of i-textbooks mentioned by teachers is the use of animations, simulations and different games, through which learners are able to better memorise content. They also emphasised that i-textbooks present more possibilities for different types of tasks and for the real-time tracking of acquired knowledge, and that they contribute to the improved motivation of learners. Čadež (2012) stated that the improved motivation of learners can only be exploited by the teacher if two basic conditions are met: 1) the teacher must be digitally literate; and 2) the appropriate technical conditions (e.g. desktop or laptop computer/ tablet and internet connection) must be in place. As disadvantages, teachers indicated that i-textbooks do not facilitate a simple overview of work performed or back-checking, as answers are not saved.
Half of all teachers said that a combination of traditional and electronic textbooks for lessons would be appropriate.

Teachers emphasised that i-textbooks must motivate learners to achieve improved understanding through active learning, critical assessment and cooperation. Most teachers (75\%) said that the use of i-textbooks was useful, but only as an additional tool used while applying traditional teaching and learning methods. They also emphasised that, in principle, memorising was a slightly better method. However, memorising can also be influenced by certain other elements such as a teacher's method of motivation, the environment, learners' level of self-motivation, etc. Another interesting remark made by teachers was that memorising was the same when learners take notes in their notebooks, regardless of whether they used an e-textbook or a traditional textbook.

Teachers also stated the following as advantages of i-textbooks: the use of multimedia, easy to update, variety of learning options, flipped learning, interactivity and improved imagination. They stated the following as disadvantages: 1) i-textbooks require a medium, otherwise they are useless; 2 ) i-textbooks must keep pace with new technological solutions, or they will become static and uninteresting; 3 ) writing is subject to neglect if $\mathrm{i}$-textbooks are used constantly; 4) the inability to save answers; 5) answers are readily available, allowing learners to simply copy them; and 6) decreased interaction between teacher and learner.

A total of $42 \%$ of teachers said that they would not add anything to i-textbooks, while $58 \%$ of teacher disagreed and suggested following: 1) i-textbooks for the Slovene language should have excerpts, multimedia presentations of different literary periods, excerpts from documentaries, broadcasts, multimedia links and more interactive tasks; 2) scrolling between pages should be easier; 3) statistical data regarding answers would be useful; 4) different possibilities for adding new tasks and modulus is desirable; 5) i-textbooks for children with special needs should also be developed (note: according to the relevant evaluation report (Flogie and Čuk, 2015), the adaptation of e-textbooks for learners with special needs and learners from bilingual regions is already planned in the future); and 6) learners should have a username in the future. The idea is that each learner should have a profile where information could be stored about what a learner has already read and processed. Because answers will be saved, learners will also have more opportunities to self-check and consolidate their knowledge.

\section{Slovenian E-learning Materials}

According to the Rules on the approval of textbooks (2015), textbooks may take printed, electronic or printed and electronic form. According to the aforementioned rules, e-textbooks are divided into two levels: $d$-text- 
books that are digitalised editions of printed textbooks and include only text and figures; and i-textbooks that include interactive elements, constructions and interactive tasks with multiple feedback to the text, and the storing of results and monitoring of users. If a textbook corresponds to the curriculum for which it is intended, the Council of Experts for General Education approves it in accordance with the procedure described in the rules.

Among the numerous textbooks approved for primary and secondary school, 27 i-textbooks (Zavod Republike Slovenije za šolstvo, 2015c) have been approved for primary school and 12 for secondary school. All i-textbooks were issued by the National Education Institute Slovenia in the E-Schoolbag and E-textbooks emphasising natural sciences in primary school projects in 2014 and 2015. Many authors, illustrators, animators, reviewers and other experts from different fields were included in the development of i-textbooks, together with Slovenian companies that offered support during the development process. I-textbooks are freely accessible, and may be used in schools and at home, free of charge. They can be used on computers and tablets that run Windows, Android and iOS operating systems, and can be used online or downloaded using different clients and used offline on mobile devices. I-textbooks that have already received official approval cover the following subjects: the Slovene, English and German languages, mathematics, chemistry, natural sciences and techniques, physics, geography, music and fine arts. An i-textbook for sport is currently in the approval process (Zavod Republike Slovenije za šolstvo, 2015a). In addition to approved i-textbooks, a list of other e-learning materials developed through tenders issued by the Ministry of Education, Science and Sport are collected on the SIO. si portal (SIO Slovensko izobraževalno omrežje, 2015). In our research, we analysed the e-learning materials found on this portal, and discovered that many are inactive. For example, the E-um portal (www.e-um.si), where mathematical tasks for primary and secondary schools are available, was last updated in 2015. The same problem was identified with the Nauk.si web portal (www. nauka.si), which was developed for mathematics (for secondary school), and for physics, logic and computer sciences (for primary and secondary schools). The portal was developed by the NAUK Group, which was formed by the Faculty of Mathematics and Physics at the University of Ljubljana. The idea was to put teachers "back in the game", as their role in developing e-materials is often neglected (Lokar, 2010). The e-gradiva web portal (www.egradiva.si) appears more active and offers e-content from different subject areas, while different news is also available on their Facebook page. A great deal of the e-learning materials developed by different schools and companies are unavailable, or web portals do not exist. All those e-portals were developed in the scope of different projects. Unfortunately, it seems that maintaining existing e-learning materials was overlooked.
Another e-portal that should be mentioned and is freely accessible is Učiteljska.net (www.uciteljska. net). This e-platform was edited in 2003 and is still active. It is intended for teachers, students and other pedagogical workers. It offers the free exchange and use of school learning materials, preparations, seminar papers, tests, exercises, articles, etc., all of which are edited voluntarily by teachers.

E-learning materials are also developed and offered by different Slovenian publishers. E-learning materials are usually available on web portals, the most popular of which are i-Modrian, Lilibi.si, Radovednih pet, iRokus, iRokust, Vedeževo e-okolje, Naša ulica and UČıMte.com. E-textbooks, e-workbooks and other different multimedia and interactive materials can be accessed on those portals. E-textbooks are substantially and formally identical to printed editions, as those textbooks are approved by the Council of Experts for General Education. E-textbooks and e-workbooks on some of the aforementioned portals have a simple toolbar, which allows a user to scroll through the pages, write and draw on the pages, tag words, enter notes, add web links and enlarge individual parts of a page. Some e-materials are also created as multimedia-interactive pages enriched with videos, 3D models, sound records, animations, interactive tasks and other add-ons. Some platforms also include an LMS, through which teachers can monitor certain activities relating to learners or groups of learners, create their own tests and surveys, create and follow activities using a working calendar, select additional media materials, and track statistics regarding the success and progress of an individual or group of learners. On the other hand, success in solving tasks in relation to an entire group is also available to learners. Some platforms are freely accessible, while others require payment. On the latter, teachers and learners receive access to portals at the beginning of the scholastic year, typically in conjunction with a learning kit that includes printed versions of textbooks, workbooks and other accessories.

A few companies offer web portals with interactive tasks for specific subjects. One of them is Moja matematika, where interactive mathematical tasks are available from the first to fifth grades of primary school. Although this portal requires payment, it has functioned successfully for more than five years, mainly because tasks are interesting, useful and regularly updated with the new challenges. In addition, each learner can trace their own success in solving tasks and also in relation to other learners.

Textbooks for students in higher education are usually published by a university faculty member. Some textbooks are already published as d-textbook. However, no i-textbook was found on the market for students.

As is evident from the data obtained, learners and teachers in Slovenian primary and secondary schools 
have significant opportunities to use the e-learning materials that have been developed over the last few years. Since the 2007/2008 scholastic year, teachers autonomously select textbooks from a catalogue, which lists textbooks approved by the Council of Experts for General Education. It is thus the teacher's responsibility to choose the most suitable learning materials for their learners. According to an analysis performed during the 2012/2013 scholastic year, the most effective and most frequently chosen combination by teachers today is the use of a printed textbook and e-learning materials (Potočnik \& Logaj, 2017).

\section{Conclusions}

The creation of an e-textbook is a complex process in organisational and technical terms. If activities are not appropriately organised, delays will be encountered in that process. Technical problems are associated with older versions of programs, incompatibility with other IT equipment, etc.

The results of our research among teachers are similar to the results of the E-Schoolbag project. The teachers who participated in our research claim that i-learning materials with additional interactive content are motivationally important for teachers and learners. Teachers are able to motivate learners easily using i-learning materials. However, i-learning materials will not completely replace printed/traditional learning materials, as learners still prefer to use printed versions of materials over digitalised materials for learning in school or at home.

According to the results of an analysis of the Slovenian market, 39 i-textbooks have been developed and approved for use in primary and secondary schools in Slovenia. All of those i-textbooks have been issued by the National Education Institute Slovenia and are freeIy accessible. In addition, several publishers develop e-learning materials. Those materials come in different forms such as digitalised printed versions of textbooks or workbooks, which in some cases have multimedia and interactive elements. E-learning materials are also offered on different platforms, some of which require payment and some of which are free. Some materials are active, while others are not. As was communicated to us through interviews, the problems associated with the continued use of e-textbooks are more pedagogical than technical. Open issues include: how to change current ways of teaching; how to use e-textbooks as an effective tool for teachers and learners; how to instruct teachers on changing their teaching plans, etc. On the other hand, Flogie and Čuk (2015) believe that the lifespan of e-learning materials and e-services in Slovenia, despite proven their effectiveness, is currently equal to the duration of the associated projects. They suggest that it is necessary to find effective and lasting systemic solutions for editing and maintaining existing e-learning materials and e-services, and for providing technical support for new ideas as they emerge and for the implementation thereof.

Numerous of projects have been implemented in Slovenia in recent years with the aim of introducing the appropriate ICT infrastructure, competent teacher principles and e-learning materials in primary and secondary schools. ICT are also being introduced at higher education institutions via minor projects, but to a lesser extent. Although Slovenia is not deemed a stand-out country in terms of digitalisation, new projects in that field are planned, while some have already been started. Taking into account all of the above facts, we can conclude that the introduction of $\mathrm{ICT}$, and thus e-learning materials, is necessary and, most importantly, required for future generations.

\section{References}

Bregar, L., Zagmajster, M. \& Radovan, M. (2010) Osnove e-izobraževanja. Ljubljana, Androgoški center Slovenije.

Calcaterra, A., Antonietti, A. \& Underwood, J. (2005) Cognitive style, hypermedia navigation and learning. Computers \& Education, 44, 441-457. Available from: doi: 10.1016/j. compedu.2004.04.007 [Accessed 3rd October 2017].

Čadež, S. (2012) Digitalno opismenjevanje s pomočjo spletne učilnice. Didakta, 22 (159), 34-35.

Digital Slovenia (2016) Digital Slovenia 2020 - Development strategy for the information society until 2020. Available from: http://www.mju.gov.si/ fileadmin/mju.gov.si/pageuploads/DID/Informacijska_druzba/pdf/DSI_2020_3-2016_pic1. pdf [Accessed 28th September 2017].

EU Kids Online. (2014) EU Kids Online Findings methods recommendations. Available from: https://Isedesignunit.com/EUKidsOnline/index. html? $r=64$ [Accessed 5th October 2017].

Flogie, A. \& Čuk, A. (2015) Kaj nam prinaša projekt e-Šolska torba. In A. Sambolić Beganović \& A. Čuk (eds.) Kaj nam prinaša e-Šolska torba. Zbornik zaključne konference projekta e-Šolska torba, 27-29 May 2015, Kranjska Gora, Slovenia. Kranjska gora, Zavod Republike Slovenije za šolstvo. pp. 21-30.

Flogie, A., Milekšič, V., Čuk, A. \& Jelen, S. (2014) Razvoj sodobnega e-okolja in i-učbenikov za področje družboslovja v okviru projekta e-Šolska torba. In: I., Zmazek, B., Milekšič, V. Pesek (eds.) Slovenski i-učbeniki. Ljubljana, Zavod Republike Slovenije za šolstvo, pp. 212-227.

Hamed, M.A. \& Ezaleil, S. M. (2015) Digital Textbook Program in Malaysia: Lessons from South Korea. Pub Res Q., 31, 244-257. Available from: doi: 10.1007/ s12109-015-9425-4 [Accessed 4th October 2017]. Hopson, M.H., Simms, R.L. \& Knezek, G.A. (2001) Using a Technology-Enriched Environment to Improve 
Higher-Order Thinking Skills. Journal of Research on Technology in Education. 34 (2), 109-119. Available from: doi: 10.1080/15391523.2001.10782338 [Accessed 4th October 2017].

Hren, M. \& Dinevski, D. (2012/2013) Stanje na področju e-učbenikov v Sloveniji. Didakta, 80 (1), 14-16.

Kelenc, A., Kos, T., Kren, M. \& Pesek, I. (2011) eXeCuteavtorsko orodje za izdelavo e-gradiv. In: A. Trstenjak, B. Blagus, K. Kosta, M. Bačnik (eds.), Mednarodna konferenca Splet izobraževanja in raziskovanja z IKT - SIRikt 2011, 13-16 April 2011, Kranjska Gora, Slovenia. Ljubljana, Miška, d.o.o. pp. 1123-1125.

Krajnc, R. (2011) How to Keep Enthusiasm for Using ICT After Experience with the First e-class at Our School. In: A. Trstenjak, B. Blagus, K. Kosta, M. Bačnik (eds.), Mednarodna konferenca Splet izobraževanja in raziskovanja z IKT - SIRikt 2011, 13-16 April 2011, Kranjska Gora, Slovenia. Ljubljana, Miška, d.o.o. pp. 218-223.

Kreuh, N., Kač, L. \& Mohorčič, G. (2011) Izhodišča za izdelavo e-učbenikov. Ljubljana, Zavod RS za šolstvo.

Lesjak, D. (2006) Akcijski načrt nadaljn-

jega preskoka informatizacije šolstva. Ljubljana, Ministrstvo za šolstvo in šport.

Lokar, M. (2010) Re-using teaching material. International Journal for Technology in Mathematics Education. 16 (1), 37-42. Available from: https://www. researchgate.net/publication/228358573_Re-using_teaching_materials [Accessed 5th October 2017].

Mayer, R.E. \& Moreno, R. (2002) Aids to computer-based multimedia learning. Learning and Instruction. 12, 107-119. Available from: doi: 10.1016/s09594752(01)00018-4 [Accessed 29th September 2017].

McGowan, M.K., Stephens, P.R. \& West, C. (2009) Student perception of electronic textbooks. Issues in Information Systems. 10 (2), 459-465. Available from: http://www.iacis.org/iis/2009/ P2009_1299.pdf [Accessed 2nd October 2017].

Ministrstvo za izobraževanje in šport (2015) Edustore. Available from: https://eucenje. sio.si [Accessed 3rd October 2017].

Ministrstvo za izobraževanje, znanost in šport (2016) Projekt e-šolstvo. Available from: www. mizs.gov.si/si/delovna_podrocja/direktorat_ za_investicije/ikt_v_solstvu/sredisce_za_e_solstvo/ [Accessed 27th September 2017].

Noriyuki, I. \& Chunming, G. (2014) A Study of Using Handwritten Annotations on Digital Textbooks. In IIAl 3rd International Conference on Advanced Applied Informatics, IIAI AAI 2014, 31 August - 4 September 2014, Kitakyushu, Japan. New Jersey, IEEE. pp. 287 - 290. Available from: doi: 10.1109/ iiai-aai.2014.66 [Accessed 4th October 2017].

O`Bannon, B. W., Skolits, G.j. \& Lubke, J. K. (2017) The Influence of Digital Interactive Textbook Instruction on Student Learning Preferences, Outcomes, and Motivation. Journal of Research on Technology in Education. 49 (3-4), 1-14. Avail- able from: doi: 10.1080/15391523.2017.1303798 [Accessed 3rd October 2017].

OECD (2009) Beyond Textbooks: Digital Learning Resources as Systematic Innovation in the Nordic Countries. Paris, OECD Publishing. Available from: doi: 10.1787/9789264067813en [Accessed 5th October 2017].

Official Gazette of the Republic of Slovenia (2015) Rules on the approval of textbooks 34, 3771-3773.

Pesek, I. (2013) Projekt E-učbeniki s poudarkom naravoslovnih predmetov $v$ osnovni šoli. Ljubljana, Zavod Republike Slovenije za šolstvo. Available from: http:// www.zrss.si/projektiess/gradiva/Projekt_9_eucbeniki.pdf [Accessed 30th September 2017].

Pesek, I., Zmazek, B., Mohorčič, G. (2014) Od e-gradiv do i-učbenikov. In: I., Zmazek, B., Milekšič, V. Pesek (eds.) Slovenski i-učbeniki. Ljubljana, Zavod Republike Slovenije za šolstvo, pp. 9-17.

Pesek, I., Zmazek, B., Mohorčič, G. \& Milekšič, V. (2014) Projekt e-učbeniki pri naravoslovnih predmetih v osnovni šoli. In: I., Zmazek, B., Milekšič, V. Pesek (eds.) Slovenski i-učbeniki. Ljubljana, Zavod Republike Slovenije za šolstvo, pp. 17-27.

Potočnik, N. \& Logaj, V. (2017) Priporočila za izbiro učbenikov in kompletov učnih gradiv za šolsko leto 2017/18. Ljubljana, Zavod Republike Slovenije za šolstvo.

Rockinson-Szapkiw, A.J., Courduff, J., Carter, K. \& Bennett, D. (2013) Electronic versus traditional print textbooks: A comparison study on the influence of university students' learning. Computers \& Education, 63, 259-266. Available from: doi: 10.1016/j. compedu.2012.11.022 [Accessed 2nd October 2017].

Sambolić Beganović, A. \& Čuk, A. (2016) Kaj nam prinaša e-Šolska torba II. Primeri obetavnih praks in evalvacija projekta. Ljubljana, Zavod Republike Slovenije za šolstvo.

SIO Slovensko izobraževalno omrežje (2015) Zbirka gradiv na portalu SIO. Available from: http://portal. sio.si/gradiva [Accessed 3rd October 2017].

Slashdot Media (2017) Sourceforge.net - Spletno mesto odprtokodnih rešitev. Available from: https:// sourceforge. net [Accessed 3rd October 2017].

Slovensko izobraževalno omrežje (2013) E-šolska torba. Available from: http://projekt.sio.si/e-solska-torba/ [Accessed 5th October 2017].

Stankovič, J. (2010) Tematska številka Biltena E-šolstvo. Predstavitev projekta E-šolstvo za srečanje ravnateljev. Ljubljana, E-središče v okviru projekta E-šolstvo.

Vlada republike Slovenije (2007) Strategija razvoja informacijske družbe v Republiki Sloveniji si2010. Ljubljana, Ministrstvo za visoko šolstvo, znanost in tehnologijo, Direktorat za informacijsko družbo.

Zabukovec, V. \& Vilar, P. (2016) Printed or electronic materials - which support active study?. In K. Aškerc (ed.), Mednarodna konferenca Kakovost visokošolskega učenja in poučevanja, CMEPIUS, 6 April 2016, Brdo pri Kranju, Slovenia. Ljubljana, Narodna in univerzitetna knjižnica. pp. 241-249. 
Available from: https://www.cmepius.si/wp-content/uploads/2014/02/1-ZBORNIK-OBLIKOVAN-

JE-final-5.pdf [Accessed 3rd October 2017].

Zahlut, A. (2011) E-education and e-learning in Austria.

The current situation and future strategies for a successful integration of e-learning in class under the circumstances of the information society. In: A. Trstenjak, B. Blagus, K. Kosta, M. Bačnik (eds.), Mednarodna konferenca Splet izobraževanja in raziskovanja z IKT - SIRikt 2011, 13-16 April 2011, Kranjska Gora, Slovenia. Ljubljana, Miška, d.o.o. pp. 132-139.

Zavod Republike Slovenije za šolstvo (2015a) Vključimo v pouk e-učbenike. Available from: http:// www.zrss.si/project/vkljucimo-v-pouk-e-ucbenike [Accessed 4th October 2017].

Zavod Republike Slovenije za šolstvo (2015b) eUrejevalnik - Spletno mesto urejevalnika interaktivnih učbenikov. Available from: https://eurejevalnik.sio. si/login/?next=/ [Accessed 4th October 2017].

Zavod Republike Slovenije za šolstvo (2015c) I-učbeniki Spletno mesto interaktivnih učbenikov. Available from: https://eucbeniki.sio.si [Accessed 3rd October 2017].

Zheng, R., Miller, S. M., Snelbecker, G.E. \& Cohen. I.

(2006) Use of Multimedia for Problem-Solving Tasks. Tech., Inst., Cognition and Learning. 3, 135-143.

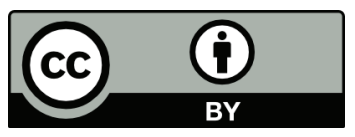

(C) 2018 Authors. Published by the University of Novi Sad, Faculty of Technical Sciences, Department of Graphic Engineering and Design. This article is an open access article distributed under the terms and conditions of the Creative Commons Attribution license 3.0 Serbia (http://creativecommons.org/licenses/by/3.0/rs/). 